\title{
Una exposición mostrará los bienes muebles ya restaurados de la Iglesia del Salvador
}

EI IAPH ha venido desarrollado, a lo largo de cuatro años, el Programa de Conservación de la colección artística de la Iglesia del Salvador de Sevilla sobre un total de 53 bienes muebles (ver PH 59, pp. 40-63). Ahora, a iniciativa de la Consejería de Cultura, está realizando el Proyecto Expositivo que dará a conocer los bienes ya restaurados que comprenden dicha colección durante la exposición temporal que tendrá lugar entre el 30 de octubre y el 9 de diciembre de 2007 en la sala de exposiciones del apeadero de los Reales Alcázares de Sevilla.

(- Ángel lamparero de la Colegial del Salvador de Sevilla / José MANUEL SANTOS MADRID, IAPH

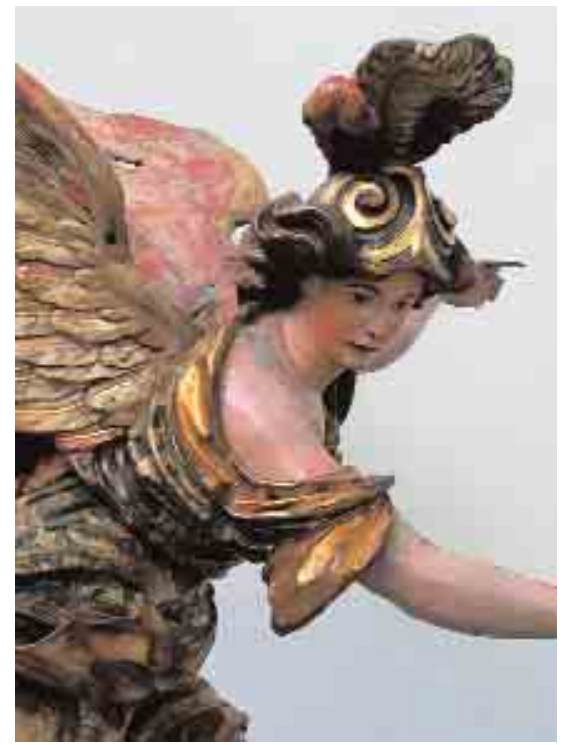

La Institución andaluza está trabajando en la elaboración de los distintos contenidos que conformarán la exposición de las piezas restauradas, desde la recopilación y selección de las obras hasta la producción de los paneles, cartelas, tarjetas de difusión y catálogos que ellas generen, incluyendo el diseño de todos aquellos elementos, técnicos y científicos, que apoyen el discurso museológico y museográfico.

Entre los objetivos fundamentales de la exposición se encuentra el de poner en valor los bienes muebles recientemente restaurados. Se trata de una oportunidad única para poder contemplar artísticamente, de modo aislado, la mayoría de estas piezas, ya que a su regreso a la antigua Colegial del Salvador quedarán incluidas en el panorama iconográfico y litúrgico del templo.

Asimismo se pretende poner de manifiesto el rigor científico (metodología, criterios contrastados, etc.) con el que el Instituto Andaluz del Patrimonio Histórico ha acometido la restauración de una colección de obras de arte en distinto soporte (pictórico, escultórico, metal, tejido y documental), recuperadas para la famosa iglesia sevillana.
El Programa Museológico desarrollará un discurso cronológico basado en los hitos históricos y artísticos, donde los bienes se aglutinarán en torno a cinco núcleos narrativos, relacionados con la historia material de la Iglesia del Salvador.

La presentación de todas las piezas en unas condiciones espaciales adecuadas para su correcta contemplación se ha considerado como criterio museográfico prioritario. La creación de una serie de recorridos responde a la idea de transmitir una información generalista, capaz de contextualizar cada uno de los núcleos expositivos dentro de la evolución del templo y de su proceso de restauración, así como de establecer un orden de lectura / recorrido.

Con carácter general, todos los núcleos narrativos contienen bienes de distinta tipología, por lo que en cada uno de ellos se desarrollarán, con un mismo lenguaje y tectónica, soportes expositivos de diferente naturaleza: vitrinas para piezas de papel y orfebrería, peanas para esculturas y soportes murales para tejidos y pinturas.

Eva Villanueva Romero 